\title{
Model analysis of service satisfaction as the modulator between service quality and decision-making behavior in using low-cost airlines
}

\author{
Sumalee Ramanust, Tikhamporn Punluekdej \& Yaowalak Nakvichien \\ Southeast Asia University, Bangkok, Thailand
}

\begin{abstract}
This research has its objectives to study 1) service-quality, service-satisfaction, and decision-making behavior in using low-cost airlines, and 2) service-satisfaction of the customers as a modulator between servicequality and decision-making behavior of the low-cost airline passengers. The sample size was 400 passengers of the low-cost airline at domestic departure building of Don Muang International Airport, Bangkok, Thailand. The statis-tics used were the frequency, percentage, mean, standard deviation, and the structural model equation analysis by PLS-Graph 3.0. The research population was passengers of the low-cost airline aged between 31-40 years old, sin-gle, holding a bachelor degree, having an average monthly income of THB 20,001-30,000, and working in private organizations. Service-quality, service-satisfaction, and decision-making behavior are at the high level. The structur-al model equation analysis indicates that service-satisfaction has an effect on the relationship between service-quality and decision-making behavior in using low-cost airlines.
\end{abstract}

Keywords: service-quality, service-satisfaction, decision-making behavior

\section{INTRODUCTION}

Nowadays, there is an increasing number of businesses in the tourism industry. No matter what types of busi-nesses, service-quality is always in the prime interest of all businesses. In order to make customers satisfied with the products and/or services, airline businesses pay their full attention towards service-quality in performing their business operations. Airline businesses have an important role in communication and transportation in Thailand. Based on econom-ic consideration, people tend to search for lower trans-portation alternatives in order to lower their travelling expenditures. To capture the demand, the low-cost airlines have immerged. Lowcost airlines are popular among the passengers who are cost-conscious. Since the prices of the low-cost airlines are quite competitive, most of the low-cost airlines turn their attention towards service-quality in the hope to make a difference in consumers' perspective in making choices.

This research was conducted in accordance with concepts and/or theory concerning service-quality, customer satisfaction, and decision-making behavior as follows:

First, Service Quality: Service quality refers to the re-sponse towards the expectation of the service-users
(Lewis \& Bloom 1983). Rust \& Zahorik (1993) stated that service-quality is processes that satisfy satisfac-tion and expectation of a person based on a concept that considers the relationship between service-quality and satisfaction. Bitner (1992) mentioned that service-quality is a comparison between service expec-tation and service perception from the service provider. If the service-provider can render service in responding to the existing need or higher than the existing need, this will make serviceuser satisfied with the services. Parasuraman et al. (1985), Fitzsimmons (2000), Kotler \& Anderson (1987) demonstrated that service quality is about the appraisal of opinion on service-excellence in the overall perception. Therefore, service-satisfaction has a direct relation-ship with the confirmation or disconfirmation of expectation of the consumers.

Second, Customer Satisfaction: Customer satisfaction refers to the level of positive feelings towards one person or thing. Shelly (1975) postulated that satisfaction can be understood as positive or negative attitudes. Positive thinking creates happiness while negative thought obstructs the exercise of our full potential creating inferior feelings. Then, the service operations desperately need a modern marketing strategy that makes the patron of service feel happy. Service-satisfaction is very important for the effec- 
tiveness of service-operations. In this respect, Zeithaml et al. (2009) said that customer's satisfaction is composed of 5 factors, namely, service-quality, product-quality, price, promotion, and process. These factors are not only crucial to customer's per-ception on the perceived performance of the organiza-tion but also are compared with the expectation. And, the results are the level of satisfaction or dissatisfac-tion (Kotler \& Armstrong 2010).

Third, Decision-making behavior: It refers to the study of human behavior with the objectives to find out customer needs and wants. This leads to the formation of marketing strategy in response to the needs of service-users in which it genuinely affects satisfaction and leading to decision-making in using the services (Kotler \& Keller 2006, McCarthy \& Perreault 1981). All in all, consumer behavior can be defined as the demonstration of an individual or a group of individuals concerning his or their decision of buying products and/or services. It shows consumers' state of mind in pursuing their needs and the portrayal of their explicit behavior with certain objectives in order to satisfy their wants and needs.

From the literature review, theory, concepts, and related research on the subject, the researchers have developed the conceptual framework based on servicequality, customer satisfaction, and consumer's decision-making behavior for passengers of the lowcost airline businesses in Thailand.

The conceptual framework is as follows:



Figure 1. Conceptual Framework.

\section{LITERATURE REVIEW}

This research is considered as a quantitative research. It was a survey research in which the questionnaires were used to gather the necessary data. The popula-tion, sample size, and the research tools were as fol-lows.
The research populations were the passengers of low-cost airlines at Domestic Departure Building, Don Muang International Airport, Thailand. The sample size was the passengers of Thai Air-Asia Air-lines with an unknown number. The sample size of 400 people was achieved through the table and calcula-tion (Yamane 1967 ) with 95\% level of confidence.

The questionnaires were divided into 2 sections: first section composes of personal data in which check-list format is used. Second until four section composes of service-quality evaluation, servicesatisfaction, and decision-making behavior of passengers of the low-cost airline. The questions utilized a Likert's rating scale. (Likert 1967). The questionnaires were reviewed by 3 experts to find out the content validity. The IOC was found between 0.67-1.00 on the items. The Cronbach's alpha was utilized and the coefficient of reliability was 0.862 indicating used (Cronbach 1974).

The total of 400 questionnaires was distributed to passengers of the low-cost airline at domestic departure building, Don Muang International Airport. The rate of return was $100 \%$. The researcher checked the com-pletion of the questionnaires and then used statistical package program to find out mean and analyze structural equation model by using PLS.

\section{DISCUSSION}

The research reveals that most of the samples were fe-males with the number of 288 persons representing $72 \%$ of the sample size, 276 persons aged between $31-40$ years old that is $69 \%$ of the sample size. Out of these, $76 \%$ or 304 persons were single. There are 328 persons or 82 percent having a bachelor degree. 296 or $74 \%$ work in private organizations. 92 of them or $46 \%$ earn a monthly income between THB 20,001-30,000.

This research discovers that the customersatisfaction is very high (3.73), followed by ser-vicequality (3.68) and decision-making behavior (3.65).

The analysis of structural equation model is as follows: 


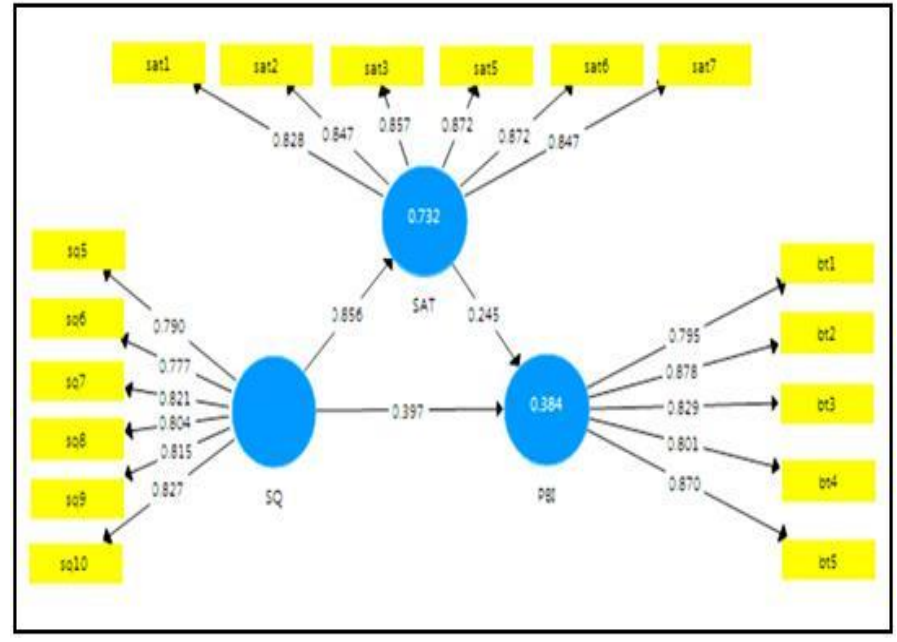

Figure 2. The analysis of structural equation modeling.

From the above figure, the analysis of structural equation modeling prevails that 1) service-quality has a direct effect on customer-satisfaction (DE = $0.86)$ and decision-making behavior $(\mathrm{DE}=0.40)$ and an indirect effect on decision-making behavior (IE = 0.61 ), and customer-satisfaction has a direct effect on decision-making behavior $(\mathrm{DE}=0.25)$.

Table 1. The relationship between influencing factors and decision-making behavior.

\begin{tabular}{lllll}
\hline $\begin{array}{l}\text { Variables } \\
(\mathrm{LV})\end{array}$ & $\begin{array}{l}\text { Variation } \\
\left(\mathrm{R}^{2}\right)\end{array}$ & Effect & SQ & SAT \\
\hline Decision-making & 0.38 & DE & $0.40^{* * *}$ & 0.25 \\
Behavior (PBI) & & IE & 0.21 & 0.00 \\
& & TE & 0.61 & 0.54 \\
Customer- & 0.73 & DE & $0.86^{* * *}$ & 0.00 \\
Satisfaction & & IE & 0.00 & 0.00 \\
(SAT) & & TE & 0.86 & 0.00
\end{tabular}

DE $=$ Direct Effect, IE $=$ Indirect Effect, $T E=$ Total Effect, $\mathrm{N} / \mathrm{A}=$ not applicable. $*$ means p-value $\leq 0.10$ or $\mathrm{t} \geq 1.65$. $* *$ means $\mathrm{p}$-value $\leq 0.05$ or $\mathrm{t} \geq 1.96$. $* * *$ means $\mathrm{p}$-value $\leq$ 0.01 or $\mathrm{t} \geq 2.58$

Table 2. Hypothesis testing.

\begin{tabular}{|c|c|c|c|c|}
\hline \multicolumn{2}{|c|}{ Hypothesis } & \multirow{2}{*}{$\begin{array}{l}\text { Coef. } \\
0.86^{* * *}\end{array}$} & \multirow{2}{*}{$\begin{array}{l}\text { t-test } \\
35.32\end{array}$} & \multirow{2}{*}{$\begin{array}{l}\text { Result } \\
\text { Supported }\end{array}$} \\
\hline H1 & $\begin{array}{l}\text { Service-quality } \\
\text { has an influence } \\
\text { on customer } \\
\text { satisfaction } \\
\text { SQ } \rightarrow \text { SAT }\end{array}$ & & & \\
\hline $\mathrm{H} 2$ & $\begin{array}{l}\text { Service-quality } \\
\text { has an influence } \\
\text { on decision- } \\
\text { making behavior } \\
\text { SQ } \rightarrow \text { PBT }\end{array}$ & $0.40 * * *$ & 2.94 & Supported \\
\hline H3 & $\begin{array}{l}\text { Customer satis- } \\
\text { faction has an } \\
\text { influence on } \\
\text { decision-making } \\
\text { Behavior } \\
\text { SAT } \rightarrow \text { PBI }\end{array}$ & 0.25 & 1.63 & $\begin{array}{l}\text { Not } \\
\text { Supported }\end{array}$ \\
\hline
\end{tabular}

The analysis of structural equation modeling on cus-tomer-satisfaction as an influencing modulator be-tween service-quality and decision-making behavior in using low-cost airline is as follows (see on Table 1).

From Table 2, service-quality has an influence on customer-satisfaction and decision -making behavior. Moreover, customer-satisfaction has an influence on decision-making behavior.

The influencing factor as a modulator (mediator effect) between service-quality and decision-making behavior is shown in the following Table 3.

Table 3. The mediator effect on service-quality and decisionmaking behavior

\begin{tabular}{lllll}
\hline Hyphotesis & $\begin{array}{l}\text { Indirect } \\
\text { Effect }\end{array}$ & $\begin{array}{l}\text { Boot } \\
\text { SE }\end{array}$ & $\begin{array}{l}\text { Boot } \\
\text { LLCI }\end{array}$ & $\begin{array}{l}\text { Boot } \\
\text { ULCT }\end{array}$ \\
\hline $\begin{array}{l}\text { An indirect-effect } \\
\text { of service-quality } \\
\text { upon customer- }\end{array}$ & 0.57 & 0.11 & 0.35 & 0.80 \\
$\begin{array}{l}\text { satisfaction and } \\
\text { decision-making }\end{array}$ & & & & \\
$\begin{array}{l}\text { behavior } \\
(\mathrm{SQ} \rightarrow \text { SAT } \rightarrow \text { PBI) }\end{array}$ & & & & \\
\end{tabular}

From the above Table 3, the service-quality has an indirect effect on the customer-satisfaction and decision-making behavior, having customersatisfaction as a mediator.

\section{CONCLUSION}

The study finds that service-quality has an effect on customer-satisfaction and decision-making behavior. This is of relevance to a research conducted by Rust, \& Zahorik (1993) on service-quality as an expansion of service processes in which it can serve or create satisfaction upon the expectation of the individuals. The basic idea of service-quality being seen through perception and satisfaction is also sup-ported by Bitner (1992).

The research discovers that customer-satisfaction has an effect on decision-making behavior and satis-faction being a mediator between service-quality and decisionmaking behavior in choosing a low-cost airline. This conclusion is in line with the study of Dennard (2000) who examined factor that has an ef-fect on satisfaction and decision-making behavior of students in the university. The study is about the attitude and behavior of students in choosing a university. The factors affecting choice are personal acceptance, social acceptance, institutional credibility, and motivation and expectation of the family. The study also indicates that satisfaction affects choices they make.

There should be a study on marketing strategy in order to promote potential in competition and create 
added value to the products and/or services. There also should be a study on another airline both premiums as well as low-cost airlines.

\section{REFERENCES}

Bitner, M.J. 1992. Servicescapes: the impact of physical surroundings on customers and employees. Journal of Marketing 56(2): 57-71.

Cronbach, L.J. 1974. Essentials of psychology testing. New York: Harper and Row.

Dennard, E.A. 2000. The Influence of psychosocial factors on college choice and subsequent student satisfaction with college experiences. Dissertation Abstract International 40(8): 2124-A.

Fitzsimmons, M.R. 2000. Asymmetric magnetization reversal in exchange-biased hysteresis loops. Physical review letters 84(17): 3986.

Kotler \& Armstrong, G. 2010. Principles of marketing. 13th ed. New York: Pearson Education.

Kotler, P. \& Anderson, A.R. 1987. Strategic marketing for nonprofit organizations. Englewood Cliffs.

Kotler, P. \& Keller, K.L. 2006. Marketing management. 12th ed. Upper Saddle River, NJ: Prentice Hall.

Lewis \& Bloom, Benjamin S. 1983. Human characteristics and school learning. New York: McGrew-Hill Book.

Likert, R. 1967. "The Method of constructing and attitude scale". In Reading in Fishbeic, $M$ (Ed.), Attitude Theory and Measurement.. New York: Wiley \& Son.

McCarthy, E.J. \& Perreault, W.D., Jr. 1981. Basic marketing. Homewood. IL: Richard D. Irwin.

Parasuraman, A., Zeithaml, V.A., \& Berry, L.L. 1985. A conceptual model of service quality and its implications for future research. Journal of Marketing 49(4): 41-50.

Rust, R.T. \& Zahorik, A.J. 1993. Customer satisfaction, customer retention, and market share. Journal of retailing 69(2): 193-215.

Yamane, Taro. 1967. Statistics: an introductory analysis. 2nd ed. New York: Harper \& Row.

Zeithaml, V.A., Bitner, M.J., \& Gremler, D.D. 2009. Services marketing: integrating customer focus across the firm. 5th ed. Boston: McGraw Hill. 